Chicago-Kent College of Law

Scholarly Commons @ IIT Chicago-Kent College of Law

All Faculty Scholarship

Faculty Scholarship

2-1-2009

\title{
Planning for a Bull Market for Wetlands
}

Fred P. Bosselman

IIT Chicago-Kent College of Law, fbosselm@kentlaw.iit.edu

Follow this and additional works at: https://scholarship.kentlaw.iit.edu/fac_schol

Part of the Environmental Law Commons, Environmental Policy Commons, and the Natural Resources Management and Policy Commons

\section{Recommended Citation}

Fred P. Bosselman, Planning for a Bull Market for Wetlands, 61 Plan. \& Envtl. L. 4 (2009).

Available at: https://scholarship.kentlaw.iit.edu/fac_schol/731

This Article is brought to you for free and open access by the Faculty Scholarship at Scholarly Commons @ IIT Chicago-Kent College of Law. It has been accepted for inclusion in All Faculty Scholarship by an authorized administrator of Scholarly Commons @ IIT Chicago-Kent College of Law. For more information, please contact jwenger@kentlaw.iit.edu, ebarney@kentlaw.iit.edu. 


\section{Commentary}

\section{Planning for a Bull Market for Wetlands}

Fred Bosselman, FAICP

\section{INTRODUCTION}

Do wetlands have a value on the open market only as targets for destruction? This was an assumption long held by business and conservation interests alike. But we may be entering an era when this assumption is no longer valid. The potential role of wetlands in producing biofuels, reducing greenhouse gases, alleviating water pollution, conserving rare species, and mitigating wetland losses may turn some wetlands into valuable assets.

The search for a greater degree of energy independence has led to extensive research and development of homegrown biofuels that could be used in place of oil. To avoid using cropland for biofuels, research has focused on plants that grow in and adjacent to wetlands. On the drawing boards are plans for using wetlands to cultivate biofuels from algae and various exotic and bioengineered plants.

Programs to control greenhouse gases may provide even greater potential profits for wetlands managers. Wetlands store vast amounts of carbon, but they also emit large amounts of methane and smaller amounts of nitrous oxide. In a world in which greenhouse gas trading offsets have significant market value, the prospect of managing wetlands to reduce net emissions of greenhouse gases will be enticing.

Wetlands managers are also showing increasing interest in trading systems that would provide credits for reduction of water pollution or conservation

Fred Bosselman is professor of law emeritus at ChicagoKent College of Law. He teaches courses in energy law, climate change law, and biodiversity conservation. He is coauthor of Energy, Economics and the Environment (Foundation Press, 2d. ed., 2006). of wildlife. We are already developing rechniques to manage wetlands to reduce nitrogen and phosphorus pollution from wastewater treatment. Studies of methylmercury formation may lead to ways of managing wetlands to reduce the problem created by the accumulation of mercury in fish and wildlife. Species conservation banks have been growing and are receiving increased attention.

Wetland mitigation banks, which allow a wetland developer to get payments for mitigating wetland losses elsewhere, are proving increasingly popular. In addition, wetland mitigation banks recently received a boost from new federal regulations that make such banks the preferred choice for off-site mitigation of destroyed wetlands.

Some of these market-oriented projects may be quite beneficial to society while remaining compatible with the other nonmarket values that wetlands provide, such as flood control and wildlife protection. On the other hand, it is easy to imagine projects that might be incompatible with other important functions. The basic problem is that we have few standards to help us draw the line. Planners and lawyers are only beginning to give thought to wetland management. Past arguments have largely turned on whether to destroy wetlands or leave them alone.

This commentary discusses some of the types of wetland-based projects that government agencies may be asked to evaluate. Eventually, we can hope for a coordinated effort by scientists, planners, and lawyers to come up with standards and procedures for such evaluation. But before any changes in law and policy will be made, state and local government officials are likely to be asked to evaluate individual wetland management projects. The purpose of this commentary is to highlight the wide range of issues that may need to be addressed in making such an evaluation.

\section{WETLAND BIOFUELS}

The Search To Replace Petroleum

Projects to grow biofuels are receiving significant government support in the United States and throughout the world. The projected high prices of fossil fuels have made many renewable energy projects appealing economically on their own merits. Such projects are also stimulated by a widespread interest in achieving a greater degree of energy independence. And biofuel projects are particularly attractive if they can also be designed to get carbon credits. ${ }^{1}$

Biofuels have attracted big investments. Producers make lots of ethanol from corn and biodiesel from soybeans or rapeseed, but by using crops of agricultural value, biofuel producers have been accused of increasing food prices. Lester Brown, head of the Earth Policy Institute, says: "[W]e are witnessing the beginning of one of the great tragedies of history. The United States, in a misguided effort to reduce its oil insecurity by converting grain into fuel for cars, is generating global food insecurity on a scale never seen before." 2

Furthermore, some scientists argue that "because farmers worldwide are responding to higher prices and converting forest and grassland to new cropland, corn-based ethanol, instead of producing a 20 percent savings, will nearly double GHG [greenhouse gas] emissions over 30 years." 3 This has led to the search for biofuel products on 
Scientists have different opinions on the extent to which any nonnative plant should be used for biofuel production or greenhouse gas reduction.

lands that would not replace existing agriculture ${ }^{4}$ but would be capable of high productivity. ${ }^{5}$ Wetlands fit that bill. $^{6}$

\section{Wetland Vegetation}

In the United States, the search for biofuels that might replace petroleum has included studies involving the harvesting of wetland vegetation. Developers have proposed a plantation of the Asian giant reed, Arundo donax, near the Everglades, ${ }^{7}$ over the strong objection of conservation groups who point to the plant's history of invasiveness. ${ }^{8}$ Reed canary grass, Phalaris arundinacea, is also being tested for biofuel production in the United States, despite its reputation as an invasive wetland species. ${ }^{9}$

Other wetland species with invasive histories that are being tested for biofuel production include Chinese tallow (Sapium sebiferum) and castor bean (Ricinus communis), native to Africa. Some native American wetland species are being tested for biofuels elsewhere in the world, even though they have become invasive in some other countries. These include elderberry (Sambucus canadensis) and persimmon (Diospyros virginiana). ${ }^{10}$

Scientists have different opinions on the extent to which any nonnative plant should be used for biofuel production or greenhouse gas reduction. Some argue that the inevitable climate change that will occur over the next decades will make use of nonnative species necessary, ${ }^{11}$ but many other scientists find this prospect alarming ${ }^{12}$ and urge the development of tests to determine invasive potential ${ }^{13}$ or the use of sterile triploid clones of nonnative species. ${ }^{14}$

In Southeast Asia, extensive oil palm plantations are being created by clearing and burning forested peatland swamps. ${ }^{15}$ Palm oil converted to biodiesel fuel reduces carbon emissions from vehicles ${ }^{16}$ but the GHG emissions produced by the peatland conversion significantly outweigh the reduction at the consumption end of the chain ${ }^{17}$ and the loss of biodiversity is irreplaceable. ${ }^{18}$ A recent analysis found "that replacing high-carbon and high-biodiversity forest or peatland with oil-palm monocultures in an effort to reduce the use of fossil fuels will accelerate both climate change and biodiversity loss." 19

Global Seawater Inc. wants to channel seawater through canals into created wetlands and aquaculture ponds in Sonora, Mexico. ${ }^{20}$ It claims that salt-tolerant plants such as salicornia could be converted to biofuel, and the creation of more acreage for seawater would mitigate sea level rise. Although many scientists fear the project's implications for groundwater, it is attracting venture capital. ${ }^{21}$ Some countries provide subsidies for this kind of research and development project. ${ }^{22}$

One project to grow sugar cane in Kenya's Tana River delta, a major wetland area north of Mombasa, has attracted widespread opposition. Proposed sugar plantation developments would convert an area of over 270,000 acres into sugarcane plantations. The projects have received government permits, but litigation is pending. Sugar cane is a renewable and relatively inexpensive source of ethanol, but many local and international groups say the plantations and an accompanying ethanol production facility will have very detrimental effects on wetland functions. ${ }^{23}$

\section{Transgenic Plants}

The use of genetic manipulation to change the characteristics of existing plant species adds another element of controversy to biofuel production. Scientists are developing new plant cultivars that will be more tolerant of salinity and wet soils. ${ }^{24}$ One of the plant groups seen as a potential target for genetic modification is the willow (Salix spp.), which is already quite tolerant of wet conditions. ${ }^{25}$

An Aspen Institute report, Biotechnology for Biofuels, concludes that "[t]he next horizon for biotechnology will be its impact on the development of improved biomass feedstocks for biofuels production." The ideal crop will grow on land not suitable for agriculture and have a high yield in tons per acre. "Preliminary results indicate that biomass yield increases of $>300$ percent in some grass species can be achieved via genetic engineering." 26 Scientists have sequenced the genomes of a wide range of plants and microorganisms as a predicate for developing cellulosic biofuels, including plants, bacteria, and algae that grow in wetlands. ${ }^{27}$

\section{Algae}

Scientists are undertaking wide-ranging research into the development of new types of algae as a source for biodiesel. "The use of algae has potential due to their easy adaptability to growth conditions, the possibility of growing in either fresh or marine waters and avoiding the use of land." 28 Some pilot projects grow algae in enclosed photobioreactors, but photobioreactors cost about 10 times as much as open ponds, so many pilot projects grow the algae in the reactor and then inoculate open ponds with the desired species. ${ }^{29}$ When the pond eventually becomes contaminated with competing species, it is drained and sterilized before being reinoculated. ${ }^{30}$ Such a process is feasible because algae can often be harvested repeatedly at intervals of 10 days or less, and are reported to produce up to 300 times more oil for biodiesel production than traditional crops on an area basis. ${ }^{31}$

Potential inputs to algae production include such diverse sources as $\mathrm{CO}_{2}$ from power plants ${ }^{32}$ and municipal sewage waste. ${ }^{33}$ Anticipated outputs include jet fuel, biodiesel, or hydrogen. Significant amounts of venture capital have gone into a variety of algae production ventures, including money from Shell, ${ }^{34}$ Chevron, ${ }^{35}$ and Bill Gates ${ }^{36}$ as well as limited amounts of government funding from various federal agencies. European Union countries have also provided funding; the Carbon Trust, an independent company backed by the British Government, has promised up to $\$ 26$ million in funding for its Algae Biofuels Challenge. ${ }^{37}$

The scope of the plans of some of the entrepreneurs is eye-popping. Sapphire Energy, a well-financed American venture, talks about millions of barrels a day with tens of thousands of acres devoted to algae farms dotted all over the Gulf Coast and the Pacific Southwest. ${ }^{38}$ It is unlikely that projects of this 
scale would get built quickly. Scientists are still searching thousands of algae species for one "to continually dominate an open pond and have desirable biofuel properties." 39 Not only are there awesome challenges involved in the basic research on the more than 40,000 species of algae that have already been identified, ${ }^{40}$ plus the complications of genetic engineering of new varieties, but anyone pursuing permits for any sizable facility would need to deal with a host of government agencies. ${ }^{41}$

\section{Opportunities and Risks}

These examples merely illustrate the creative ingenuity that biofuels and other renewable energy projects attract. ${ }^{42}$ Wetlands are still only a minor target for such projects, but if wetland biofuels can be developed that will reduce reliance on petroleum without destroying other important wetland functions, they would create important benefits. However, it is hard to foresee all of the potential risks these projects may create. ${ }^{43}$

At the 2008 meeting of the Conference of Parties to the Convention on Wetlands ("Ramsar"), many participants expressed concern about the potential impact of biofuels on wetlands. The conference resolved that

Decisions on land use change must integrate adequate knowledge of the range of benefits, and their values, that wetlands provide for people and biodiversity. Decision making should, wherever possible, give priority to safeguarding naturally functioning wetlands and the benefits they provide, especially through ensuring the sustainability of ecosystem services, while recognizing that human-made wetland systems can also make a significant contribution to water and food security objectives. ${ }^{44}$

\section{TRADING GREENHOUSE GAS CREDITS}

\section{The Carbon Market}

\section{Carbon trading (which usually also} includes trading in other major GHGs) has developed into a big-money game that is still evolving in directions that are hard to predict. As of this writing, it has not had a big impact on wetlands, but if it follows the paths currently projected, traders will view the management of wetlands as tempting targets with high potential value. ${ }^{45}$ Some such projects may be quite compatible with other beneficial wetland functions, but others may have highly adverse impacts. Discerning the differences will be challenging.

American companies are already active participants in the European Trading System. ${ }^{46}$ The financial community looks forward eagerly to the expanded carbon trading. Many businesses expect that the United States will adopt some form of carbon trading law within a few years. ${ }^{47}$ Groups of states, such as the Western Climate Initiative (which also includes some Canadian provinces) and the Regional Greenhouse Gas Initiative, a coalition of northeastern states, are already working on their own carbon trading programs. ${ }^{48}$ "We see enormous opportunities for the financial industry," said the vice chairman of Deutsche Bank. "If leadership is there to create a Kyoto successor that is based on cap-and-trade, then it creates a global carbon market-and then we are in business." 49

The assumption is that future trading systems will be based on a cap-and-trade law. The law will establish binding limits on the tons of greenhouse gases that certain categories of sources may emit. If a particular source chooses not to limit its own emissions, it can buy credits either (1) from another source that has limited its emissions more than the law requires, or (2) from the developer of a project that will reduce emissions in a way that the law does not require; such a project is referred to as an "offset."

\section{Global Mixing Means Global Offsets}

Although the idea that a chemical company could continue its GHG emissions in France by installing equipment to reduce emissions on a plant in Korea may sound counterintuitive, ${ }^{50}$ the concept is based on the widely accepted scientific principle that greenhouse gases mix globally during their lifetimes in the atmosphere. Therefore, reducing emissions any place in the world is as good as any other. Or, as the traders like to say, a ton is a ton is a ton.
So the idea of offsets is scientifically sound. In addition, the offset project need not reduce the same gas as the gas that produces the emissions it is offsetting. The reduction only needs to add up to the same number of carbon dioxide equivalents as the gas that was emitted. Methane is 20 to 25 times as powerful as carbon dioxide, while nitrous oxide is about 300 times as powerful as carbon dioxide.

The United Nations' system of verifying Kyoto offset reductions has undergone significant growing pains. ${ }^{51}$ The details of these controversies are beyond the scope of this commentary, but they involve examples such as (1) projects that cause huge reductions of the more potent greenhouse gases at chemical plants by installing cheap equipment that other plants use in the normal course of business; (2) projects that would probably have been undertaken anyway because they are economically profitable, such as some landfill methane capture and utilization projects; or (3) projects that will produce benefits only if one assumes that conditions will remain unchanged for decades, such as restoration of forests.

The rules defining a "good" offset should and will undergo change, but it is unlikely that offsets will disappear. First, the scientific logic on which offsets are based has not been seriously challenged: a ton is a ton, wherever and whatever. Second, many countries are setting emission caps that seem impossible to achieve without offsets, ${ }^{52}$ which means that the price of credits might be high and create a big incentive for offset developers. One recent survey predicts that by 2020 carbon credits will sell for $€ 30$ per ton of carbon dioxide. ${ }^{53}$ Third, all of the parties to an offset transaction will benefit if a project is declared to be a good offset worth lots of credits, so developing a trustworthy system of neutral oversight will be challenging. ${ }^{54}$ Fourth, the participants in offset projects include some of the largest and most influential corporations in the world. The membership of the International Emission Trading Association (IETA) includes many big investment banks and multinational companies. ${ }^{55}$ These guys don't play penny ante. 


\section{Natural Emissions}

Although the arguments about climate change have focused on the issue of whether and how humans are changing the climate by emitting GHGs, it is well known that natural sources also emit large amounts of GHGs. If too many GHGs are the problem, then reducing natural GHG emissions will be as beneficial as reducing emissions from human-caused sources. ${ }^{56}$

Why are wetlands logical opportunities? First, some kinds of wetlands store enormous amounts of carbon in the form of submerged organic material, and might be managed in a way that stores more. ${ }^{57}$ Second, the prevailing scientific opinion is that methane is responsible for some 15 percent of total $\mathrm{GHG}$ emissions, ${ }^{58}$ and that natural wetlands cause about 25 percent of methane emissions. ${ }^{59}$ Third, the 2007 Intergovernmental Panel on Climate Change (IPCC) report emphasized that some wetlands are significant sources of nitrous oxide, an even more potent GHG. ${ }^{60}$ Fourth, the IPCC estimates that a doubling of carbon dioxide emissions would cause wetland methane emissions to increase by 78 percent. ${ }^{61}$

\section{Going for the Gold}

So if the goal of our laws was solely to reduce climate change-and right now the price of carbon credits is based on no other factor ${ }^{62}$ - then alteration of wetlands based solely on GHG impact could be an alchemist's tempting pot of gold. $\mathrm{C}-\mathrm{NH}_{4}-\mathrm{N}_{2} \mathrm{O}=\mathrm{Au}$.

How much gold? Any project that might be planned today would need to speculate on the price carbon credits would bring when the project was completed. ${ }^{63}$ But with credits in various world markets in the range of $\$ 20$ per ton, and various economic models projecting even higher prices, the lure is great. ${ }^{64}$

Could this entire system collapse? It's possible, but not sufficiently likely so that we can ignore the system's implications. In a recession, politicians may be slower to adopt new regulations, and some economists argue that a carbon tax would be more efficient than a cap-and-trade law, ${ }^{65}$ but many analysts think that new taxes would be even less popular. ${ }^{66}$ Nevertheless, the possibility that the market will expand and the price of credits will remain high is sufficiently likely that it pays to think in advance about the potential impact of such projects on wetlands.

\section{How Wetlands Affect GHGs}

The technical literature on managing wetlands for $\mathrm{GHG}$ reduction is growing rapidly. Most of the studies identify particular factors that appear to affect the GHG conditions on specific wetlands, and few authors pose broad generalizations. The wide-ranging results of this research emphasize how complex and site-specific any analysis of the global warming potential (GWP) impact of any particular wetland can be.

Examples of the factors affecting wetland GHGs are discussed in the studies cited below, which represent only a small sample of the literature.

Water level. Wetland soils that are continuously underwater remain anaerobic-lacking in oxygen - which can increase their ability to store carbon. ${ }^{67}$ However, bacteria that generate methane thrive in anaerobic conditions, so that deep, continuous water over wetland soils can increase methane emissions. ${ }^{68}$ In some cases, the methane from the wetland may cause a net increase of GWP despite the carbon storage that takes place. ${ }^{69}$

Periodically draining wetlands can reduce methane emissions, even to the point of creating a methane sink, ${ }_{2}^{70}$ but such drainage may increase carbon dioxide emissions, ${ }^{71}$ and some studies conducted in tropical rice fields indicate that periodic drainage increases nitrous oxide emissions. ${ }^{72}$ Natural periodic variations in water levels may also substantially reduce methane emissions, ${ }^{73}$ but some research suggests that temporary reductions in water levels may increase the release of methane bubbles. ${ }^{74}$

Restoring old wetlands by raising water levels can increase carbon storage, ${ }^{75}$ but the timing and extent of carbon buildup remains difficult to predict. ${ }^{76}$

Climate. The peatlands in northern Eurasia and North America differ greatly from coastal mangrove wetlands and forested peat swamps in the tropics. The rising arctic temperatures in recent decades have caused more emissions of methane from northern wetlands. ${ }^{77}$ Much of the arctic methane has been locked in permanently frozen ground -permafrost-and is being released as warmer temperatures cause the ground to melt in the summers. ${ }^{78}$ Subarctic peat wetlands are also affected by temperature; some models predict that warming temperatures may increase methane emissions from such wetlands, ${ }^{79}$ but it is unclear whether warming will increase or decrease carbon storage. ${ }^{80}$

One recent study of coastal tropical wetlands found that they absorb and hold 80 percent more carbon than wetlands in temperate climates, ${ }^{81}$ and coastal wetlands, in their natural condition, may have only a modest adverse impact on methane or nitrous oxide. ${ }^{82}$ Seawater inhibits methane emissions, 83 but if coastal wetlands are affected by runoff from fertilized agriculture or urban wastewater they may become substantial emitters of both methane and nitrous oxide. ${ }^{84}$ Unfortunately, such runoff is more and more common throughout the world. ${ }^{85}$

Seasonality. Emissions of GHGs from wetlands often vary greatly over a year's time, not only in cold climates, ${ }^{86}$ but in areas where rainfall is highly seasonal. A study in coastal wetlands on the Bay of Bengal found high rates of methane emissions in the November-January period and low rates in other months. ${ }^{87}$ Thus even where the year-to-year climate may be relatively constant, at least one full year's measurement would be needed to ascertain GWP impact.

Flora. Numerous studies have tried to ascertain the extent to which different species of plants create different GWP impacts. For example, forested wetlands can store lots of carbon if harvest rotation is long, ${ }^{88}$ but a study of a forested freshwater wetland in Louisiana found that the methane emissions created a net warming effect. ${ }^{89} \mathrm{~A}$ study of sedges found that they increase methane emissions in wet periods but reduce it in dry periods. ${ }^{90}$

Some studies suggest that a greater diversity of wetland vegetation reduces 
Federal and state agencies are already partnering with private projects to increase carbon sequestration in wetlands. methane output. ${ }^{91}$ Other studies found that particular species of plants seem to have adverse GHG impacts; for example, in an Irish bog, buckbean plants seemed to produce methane hotspots, ${ }^{92}$ and in an Ohio wetland, common rush was more effective in lowering methane emissions than black willow. ${ }^{93}$ Nitrous oxide may also vary with different species of wetland vegetation. A study of a Chinese wetland found that Manchurian wild rice stimulated nitrous oxide emissions. ${ }^{94}$ In India, the pneumatophores produced by Grey mangroves were found to be conduits of increased emissions of both nitrous oxide and methane. ${ }^{95}$

Algal ponds have also been studied as potential sinks for carbon storage. One study hypothesizes that one hectare of algal ponds could store up to one ton of carbon dioxide every day. ${ }^{96}$ Scientists are studying thousands of algae varieties both for carbon storage and biofuels.

Fire. Peat bog fires that occur from lightning strikes or human activities can instantly convert a carbon sink into a huge source of carbon emissions. ${ }^{97}$ Because peat is an enormous storehouse of carbon, the United Nations Environment Programme (UNEP) peatlands study identified such fires "as one of the largest sources of $\mathrm{CO}_{2}$ in the atmosphere." The burning of forested peat bogs in 1997 in Indonesia emitted some 2.6 billion tons of carbon, "equivalent to 40 per cent of global emissions from burning fossil fuels that year." 98

Nitrates. Many natural wetlands have low nitrate concentrations, so the fact that they produce some nitrous oxide through denitrification does not make them significant sources of this powerful GHG. ${ }^{99}$ However, human activities are increasingly directing runoff from fertilized agriculture into wetlands, substantially increasing nitrate volumes. One study found that wetland soils appear to convert a high proportion of fertilizer runoff to nitrous oxide rather than other nitrogen forms. ${ }^{100}$

In addition, the creation of wetlands for treatment of wastewater provides a major source of nitrates. ${ }^{101} \mathrm{~A}$ study of Brazilian wetlands that absorbed runoff from sugarcane fields suggested that the nitrous oxide emissions from the wetland cancelled out the savings from carbon storage. ${ }^{102}$ Similar conclusions were reached in a study of wastewater wetlands in the Netherlands. ${ }^{103}$ Nitrates may also affect methane production. One study suggested that the addition of wastewater to mangrove wetlands may increase methane production and destroy the ability of the trees to reproduce; ${ }^{104}$ in a Russian peat bog, however, the addition of nitrates apparently reduced methane emissions. ${ }^{105}$

Sulfates. Many tropical coastal wetlands have acid sulfate soils. ${ }^{106} \mathrm{~A}$ number of studies have shown that even small amounts of sulfates can reduce the production of methane in wetlands. ${ }^{107}$ Coastal wetlands may receive enough sulfate from seawater to neutralize methane production. ${ }^{108} \mathrm{But}$ seasonal rainfall may sometimes reduce the effectiveness of sulfates. ${ }^{109}$

Studies that simulated the effects of acid rain on inland wetlands concluded that the components of typical acid rain actually reduced methane emissions. ${ }^{110}$ Both sulfates and nitrates seemed to have that effect. ${ }^{111}$ Similar results were found in a Russian study. ${ }^{112}$

Fauna. Marsh snails have caused extensive die-offs of wetland vegetation in southern U.S. coastal areas, presumably because overharvesting of their predators led to an explosion of snail populations. ${ }^{113}$ By flooding streams in northern regions, beavers have contributed to higher methane emissions. ${ }^{114}$ Muskrats and related species dig holes in dikes and may cause wetland drainage. ${ }^{115}$ Huge flocks of geese have had dramatic impacts on Arctic wetlands, affecting their GHG balance unfavorably by destroying vegetation. ${ }^{116}$ On the other hand, one study found that Bewick's swans reduce wetland methane emissions because their foraging causes bioturbidity. ${ }^{117}$

Time. Where the climate tends to vary substantially from year to year, determining the long-range effect of a wetland on GWP may require measurement over long periods of time 118 and remains difficult to predict. ${ }^{119}$ The need to normalize the data for year-to-year climate variations adds another vari- able to the analysis. ${ }^{120}$ Newly formed wetlands are not likely to accumulate the stored carbon typical of a natural wetland for decades ${ }^{121}$ and may never achieve comparability. ${ }^{122}$

The temporal effect of ongoing climate change must also be considered. If the IPCC reports are to be used as a basis for awarding credits, then the calculations should recognize the IPCC's predictions that a substantial degree of climate change will happen before any mitigation measures can be effective. For example, if climate change is likely to increase coastal water levels, that impact should be taken into account in evaluating a coastal wetland.

These brief, nontechnical descriptions of the results of some technical studies should not be relied on as summaries of the studies themselves. The important points are (1) the wide variety of factors being studied; (2) the fact that the studies are being carried out in varying types of wetlands throughout the world; and (3) the site-specific nature of so many of the results. ${ }^{123}$ These situations illustrate the need for a great deal of additional research.

Federal and state agencies are already partnering with private projects to increase carbon sequestration in wetlands. The U.S. Geological Survey is beginning to provide grants for "carbon farms" - wetlands created to store carbon $^{124}$ _and the U.S. Fish and Wildlife Service (USFWS) is working with private landowners to replant forested wetlands. ${ }^{125}$ State and local agencies will need a lot of scientific expertise to evaluate new wetland projects designed to improve GHG performance.

If the analysis of biofuel and carbon credit values were not complex enough, consideration must be given to the possibility that wetland management may produce market-derived values from a number of other sources. These include water pollution control, water quality trading, toxic mercury control, species conservation banking, and wetland mitigation banking. Furthermore, the process of managing wetlands may involve informal tradeoffs through environmental assessments and local development exactions. 


\section{WATER QUALITY TRADING}

The U.S. Environmental Protection Agency (EPA) has been heavily promoting trading programs as an efficient way to reduce air pollutant emissions. The agency has also encouraged the states to experiment with trading systems to reduce water pollution. Although these programs are not as widespread as the air pollution programs, the possibility of receiving credits under a water quality trading program is one that a wetlands manager would want to consider if it is available.

\section{Treatment Wetlands}

Both the EPA and the U.S. Department of Agriculture have been encouraging states to develop programs for water quality trading. ${ }^{126}$ Effluent that is discharged directly into rivers from sewage treatment plants or factories carries heavy loads of nitrogen and phosphorous downstream. Agricultural fertilizers add these same elements to water bodies through runoff. If certain treatment methods can reduce nutrient inputs more cheaply than others, a trading program can be used to promote use of the most efficient methods. ${ }^{127}$ The most common example has been one in which a regulated factory obtains credits for paying an unregulated agribusiness to establish buffer zones along the riverbank to reduce agricultural runoff. ${ }^{128}$

The problem of nutrient pollution is a serious one. In the Mississippi watershed, for example, such high quantities of nutrients remain when the river reaches the Gulf that oxygen content is lost and large areas can no longer support most marine life. ${ }^{129}$ Similar "dead zones" are found in the Baltic Sea and other bodies of water. ${ }^{130}$

To alleviate this type of problem, efforts are underway throughout the world to restore riparian wetlands ${ }^{131}$ and to construct treatment wetlands ${ }^{132}$ to absorb more of these nutrients. "Because wetlands can be sinks for almost any chemical, applications of treatment wetlands are quite varied, with thousands of applications worldwide to treat domestic wastewater, mine drainage, non-point source pollution, storm water runoff, landfill leachate, and confined livestock operations." 133
Seven states have programs in effect to allow statewide trading of water quality credits. ${ }^{134}$ In some instances, constructed wetlands may serve as a source for tradable water quality credits, but it "has been an uphill battle." 135 Because there is no specific federal statutory. authority for the program, the states have many different approaches and the overall effectiveness of the programs is hard to determine. ${ }^{136}$

\section{Mercury}

In the future, the opportunity to obtain water quality credits for wetlands may improve if methods of using wetlands to reduce the toxicity of mercury become well established. Mercury causes serious health problems for pregnant women and infants. ${ }^{137}$ The primary source of mercury is airborne, but its health impacts begin after the mercury reaches water and is methylated and absorbed up the food chain to fish and wildlife. These issues do not fit neatly within our existing regulatory systems, ${ }^{138}$ and at present there are no enforceable federal regulations of mercury emissions from power plants. ${ }^{139}$

Wetlands play a key role in the conversion of atmospheric mercury to the methylmercury ( $\mathrm{MeHg}$ ) that becomes bioaccumulated in fish and other wildlife. ${ }^{140} \mathrm{~A}$ review of the literature in 2002 commented that "it is ironic that wetlands, landscape elements that both regulation and legislation have attempted to protect from disturbance, are the single most identifiable source of $\mathrm{MeHg}$ in terrestrial systems." 141

The scientific understanding of methylation is still limited, but the nature of the water body in which methylation occurs appears to play an important role. ${ }^{142}$ Measurements taken at a number of wetland sites have shown that wetlands export more $\mathrm{MeHg}$ than they receive. ${ }^{143}$ Sulfate-reducing anaerobic bacteria that appear to be causing much of the methylation thrive in wetlands, particularly in wetlands where organic carbon and sulfate are common, such as those impacted by acid rain. ${ }^{144}$

Although the science remains in flux, biotechnologists are working on methods of wetland management that counteract or limit the methylation pro- cess. ${ }^{145}$ Scientists have engineered wetland plants with bacterial genes that can convert $\mathrm{MeHg}$ to its volatile form; for example, experiments found that transgenic rice was able to convert $\mathrm{MeHg}$ to its less toxic form. ${ }^{146}$ Similar experiments have been successful with cottonwoods. ${ }^{147}$ Such research might eventually lead to regulations that would provide valuable credit for management of wetlands for $\mathrm{MeHg}$ removal.

\section{SPECIES CONSERVATION BANKS}

Species conservation banks have attracted considerable interest recently. Wetlands managers have had over a century's experience in managing wetlands for the benefit of wildlife; the USFWS, various state agencies, and nongovernmental organizations such as Ducks Unlimited have shown that wetlands can frequently be managed to improve habitat for wildlife. ${ }^{148}$ Although much of the management has been financed by duck hunters, the managers have also learned how to provide habitat for other species in need of protection. ${ }^{149}$

The idea of using banking systems to help finance wetland biodiversity is more recent and grew in recognition of the need to protect quite large wetland areas in certain places. Many species suffer when their habitat is fragmented; their chances of survival improve if they can occupy a larger habitat that may be subject to less stress from changing conditions. ${ }^{150}$ Amphibians, for example, often need both wetlands and some adjacent protected uplands in order to maintain stable populations. ${ }^{151}$ Shorebirds that migrate long distances may require large protected areas at key points on their migratory routes; for example, the Red Knot (Calidris canutus) makes one of the longest yearly migrations of any bird, traveling 9,300 miles from Tierra del Fuego at the southern tip of South America to its Arctic breeding grounds, and relies on a specific area of Delaware Bay to fuel its spring migration. ${ }^{152}$

\section{California's Program}

California has had a program in place for more than a decade that encourages the development of reserves for the protection of rare species by allowing the 
The informal legal status of conservation banks outside California has made it difficult to collect comprehensive information about their existence and operations.

managers of the reserve to sell shares in it to people who need the credits to mitigate for habitat destruction. ${ }^{153}$ Some 40 conservation banks have been created, many of which are devoted to the protection of wetlands, including rare vernal pools and wetland-upland interfaces needed by rare amphibians such as the California red-legged frog. ${ }^{154}$ The program differs from typical wetland banking by emphasizing the quality of the habitat protected rather than just the amount of acreage. ${ }^{155}$ The USFWS supports the program, and has encouraged the development of similar programs in other states. ${ }^{156}$

The informal legal status of conservation banks outside California has made it difficult to collect comprehensive information about their existence and operations. ${ }^{157} \mathrm{~A}$ study in 2003 found 76 places that were designated as conservation banks, not all of which were associated with state or federal programs. ${ }^{158}$ Congress has not specifically addressed conservation banking for the protection of species, so the rules are set forth in guidance documents issued by the USFWS rather than in statutes or regulations, which creates a risk that future statutes could change the rules retroactively. ${ }^{159}$ However, many of the conservation bank transactions are included in habitat conservation plans endorsed by the USFWS, ${ }^{160}$ and such plans have been accepted by the courts as binding contracts. ${ }^{161}$

\section{Biodiversity Offsets}

The World Bank has promoted the use of conservation banks at the international level. ${ }^{162}$ The United Nations Convention on Biological Diversity has encouraged the development of guidelines for "biodiversity offsets" and a number of countries have begun work on such programs. ${ }^{163} \mathrm{~A}$ new NGO has been created specifically to work on this subject. ${ }^{164}$

Scientists are paying specific attention to the possibility of designing biodiversity banks that might receive carbon credits under the Kyoto Protocol's clean development mechanism system. Two Australian analysts suggest that the "convergence of schemes to sequester carbon and conserve biodiversity present an opportunity to revolutionize environmental management. If correctly harnessed, the power of carbon initiatives could fuel a major biodiversity renaissance." 165

\section{WETLAND MITIGATION BANKS}

\section{Are All Wetlands Equal?}

Under federal law, a wetland that is destroyed can often be replaced by a different piece of land as long as that land is also "wet." This has led to many efforts to create wetlands that would be the equivalent in size to wetlands that developers wanted to destroy. ${ }^{166}$ The mixed results of these efforts ${ }^{167}$ led the EPA to ask the National Research Council (NRC) of the National Academies of Science and Engineering to study the effectiveness of wetland mitigation. ${ }^{168}$

The mitigation requirement arises under the permitting requirements of $\S 404$ of the Clean Water Act, which requires developers to obtain a permit from the U.S. Army Corps of Engineers (Corps) to dredge or fill certain types of wetland. ${ }^{169}$ Although the Corps' preferred alternative has been for the developer to redesign the project so it will not affect wetlands, many developers claimed that was not feasible and proposed to create new wetlands either on-site or in some other location, but the track record of this type of mitigation was not encouraging. ${ }^{170}$

The NRC found that the existing mitigation procedures needed to pay more attention to the long-term management of mitigation projects: "The presumption that once mitigation sites meet their permit criteria they will be self-sustaining in the absence of any management or care is flawed." ${ }^{171}$ It recommended that if project redesign was not feasible the developer should be encouraged to buy shares in a large created or restored wetland that would be professionally managed to maintain wetland values over the long term. ${ }^{172}$

\section{A Watershed Perspective}

In 2008, the Corps issued new regulations that endorsed many of the recommendations of the NRC. ${ }^{173}$ Wetland mitigation banks, which have been functioning in some areas for 20 years, ${ }^{174}$ now get preferred status under the new regulations. ${ }^{175}$ Development of wetland mitigation banks is encouraged in an attempt to produce larger wetland systems that will perform more functions more reliably. ${ }^{176}$ Because a person who creates a new wetland may be able to sell shares in it to developers who need to produce wetlands equivalent to the wetland they will be removing, ${ }^{177}$ the time lag between the destruction of a wetland and its replacement can be reduced. ${ }^{178}$

In addition, the regulations allow a mitigation bank to protect the permanence of existing wetlands if a watershed study has identified such preservation as a high priority. ${ }^{179}$ The NRC had emphasized that "the mitigation program would achieve greater shortand long-term results by looking at each permitting decision over a broader space and longer time period." When a plan is "viewed from a watershed perspective over a long period, the purpose is to secure a desired matrix of wetland types and locations to achieve the goals of the Clean Water Act in the watershed." 180

\section{STACKING CREDITS}

To what extent should a manager of a hypothetical wetland be given value separately for performing each of the following functions at the same time and place?

1. carbon sequestration

2. methane and nitrous oxide suppression

3. mitigating wetland destruction by others

4. performing wastewater treatment

5. protecting habitat of rare species

6. creating valuable biofuel

At first blush, every wetland management entrepreneur would relish the possibility of getting paid separately for performing each of the whole range of valuable functions discussed in this commentary, and many conservation organizations see advantages of combining multiple credits. ${ }^{181}$ But what is the risk that the stacking will be banned as "double-dipping?" 182

\section{Double-dipping}

The dictionary defines double-dipping as "the act or pracrice of receiving more 
Many of the trading programs have tried to develop rules that ensure that credits or other incentives are given to projects that would not have been feasible without the incentive.

than one income or collecting double benefits from the same employer or organization." ${ }^{183}$ But no law prevents this if it is an open transaction between parties who have full information. Corporations regularly pay officers a salary, bonus, various benefits, and stock options, each designed to reward a certain kind of performance. If there is full disclosure of information, and the rules of each separate program are met, then double-dipping should not be disqualified.

Despite the lack of any precise legal definition, double-dipping has become the slogan used by people who are concerned that trading programs may unduly reward project proponents. The concern is legitimate, but the complexity of the processes by which such projects are put together sometimes makes it very difficult to decide how many dips are too many.

For example, if the landowner received funds from one of the many government grant programs designed to promote wetland conservation, ${ }^{184}$ it could be argued that it would be an inappropriate form of double-dipping to allow the landowner to earn credits without deducting the cost of the compensation already received. On the other hand, farmers have become experts in piling various kinds of subsidies and incentives from the federal government on top of each other, and this practice is encouraged by agriculture agencies. ${ }^{185}$ Where this is the normal way of doing business, should a wetland owner be prevented from stacking various types of credits on top of these grants?

\section{Additionality}

Could biofuel projects also get wetland mitigation credits if the sale of the biofuel in a private market created compensation for the wetland owner? What if the biofuel plants also reduced the methylation of mercury or reduced the emission of methane? If a wetland improvement project could generate value on the private market and also performed valuable environmental functions, it would seem unfortunate to discourage it. Yet if the sale of the biofuel were so profitable that the project would have been undertaken in any event, the allocation of scarce credits might better be reserved for projects that would not have gone forward without them.

Many of the trading programs have tried to develop rules that ensure that credits or other incentives are given to projects that would not have been feasible without the incentive. The term "additionality" has been coined to express this idea. In the hypothetical example above, if each of the trading programs insisted on additionality, then the project developer would need to convince them that all of the separate incentives were necessary to make the project feasible. ${ }^{186}$

\section{Permanence}

How long will a particular project produce the results it seeks to achieve? This can often be one of the most difficult issues to resolve. The proponent may argue that unless the credits are received up front it will be impossible to undertake the project. But who can prove that a project will work as planned and that it will not be destroyed by fire, flood, or other unexpected events?

The debate on this issue has been particularly intense in the United Nations Clean Development Mechanism program in regard to forestry. The Kyoto Protocol gives credits for afforestation and reforestation, but the regulations limit the time period for which the credit can be awarded. When the credit expires, new temporary credits can be awarded if the project is performing properly. ${ }^{187}$

Temporary credits that are renewed periodically may better motivate a project manager to protect and maintain the project. ${ }^{188}$ If the award of credits is made periodically as the project evolves, the government will also feel more secure that the scarce credits are not being wasted, but this security may come at the expense of the most innovative and promising projects that may never receive financing because of their lack of a track record. Cautious bureaucrats may tend to approve only the most time-tested types of projects that follow authorized models, thereby stifling innovation. ${ }^{189}$ On the other hand, direct research and development grants may be the most appropriate way to encourage innovation.

\section{Leakage}

Another issue that often arises is known as "leakage." In the hypothetical, we should ask if the project would have indirect adverse impacts beyond the project's boundaries. Would the wetland plants invade neighboring areas? Would the suppression of methane involve adding chemicals that would have adverse impacts downstream? Would the use of the wetlands for sewage treatment make it unfeasible to employ a better form of treatment? ${ }^{190}$

\section{Ad Hoc Mitigation}

There are no rules of general applicability to decide whether the stacking of credits should be prohibited as double-dipping. The development of such rules seems unlikely because of the many ways that a wetland developer can obtain value indirectly. As every practitioner knows, negotiating tradeoffs is one of the primary activities of a land use or environmental lawyer. Much of this work is done in an informal context when negotiating issues relating to some particular project, and the legal basis for enforcement of such negotiations may be shaky.

Without venturing into detail, there are a few mechanisms under which such trading takes place. A vast and undocumented trading process has taken place under the National Environmental Policy Act (NEPA) and similar state statutes. Although most of the scholarly attention has been directed to NEPA's requirement of an environmental impact statement (EIS), less than one percent of the cases under NEPA reach the EIS stage. Instead, the proponent prepares an environmental assessment and negotiates with the stakeholders about what changes in the design or compensatory mitigation is required in order to avoid a challenge to the failure to prepare an EIS. The typical resolution is a "mitigated FONSI," which is a "finding of no significant impact" based on the fact that the proponent's 
The IPCC's reports suggest that the wetlands themselves

will be changing in response to climate change that has

already become unstoppable.

proposed mitigation will balance any adverse impacts to the point of insignificance. ${ }^{191}$ Although these mitigation commitments have not always been put into enforceable form, ${ }^{192}$ and comprehensive data about them will probably never become available, there are certainly cases where they have resulted in a great deal of improvement to the environment. 193

But applying these concepts to particular cases is not easy. For example, suppose a highway builder destroys some wetland acreage but proposes to create new wetlands in place of the usual borrow pits. Would the project have required an EIS if traditional borrow pits had been used? How can we ever be sure? And how would you value the time and expense of preparing the EIS? An equally undocumented forum for trading takes place at the local level when land developers agree, or are required, to do things to benefit the local community in exchange for a rezoning or other form of development permission.

Administrators of trading programs are all searching for ways to allocate credits and incentives where they will do the most good for the particular values that they are trying to protect. Perhaps some day there will be clearly defined rules that apply generally to all of these programs, but until then the developers of projects and the agencies that review them will be trying to make the best judgment in the face of vague rules and continually evolving science.

\section{CONCLUSION}

Reviewing Projects

What are the implications of all of this research and marketing for government officials who will be asked to review proposed projects?

First, they should get a thorough analysis of the reliability of the project's potential impact. The profit these projects plan to generate should enable the developer to finance such studies by independent experts.

Second, don't be surprised if all that the scientists can tell you is "let's try it and wait and see." Adaptive management may be feasible for the developer if credits will be given to the project periodically based on periodical results. ${ }^{194}$

Third, remember that leaving wetlands alone may not be an option for maintaining the status quo. ${ }^{195}$ The IPCC's reports suggest that the wetlands themselves will be changing in response to climate change that has already become unstoppable. ${ }^{196}$ These changes are likely to produce complex and unpredictable feedback effects ${ }^{197}$ especially for coastal wetlands. ${ }^{198}$

\section{Breakthroughs and Shell Games}

This commentary should really be viewed from at least two perspectives. First, the interplay of all of these programs provides challenging opportunities to develop new, creative methods of wetlands management that could provide great benefits for a number of important objectives. Scientists, planners, and lawyers ought to focus on ways to ensure that future regulations will encourage such projects.

Second, the large amounts of money at stake will tempt project developers to find loopholes in whatever regulations are adopted, so public scrutiny must be timely, comprehensive, and detached. Processes to make scientific expertise available for such reviews are needed. ${ }^{199}$

A third perspective, of course, would consider the basic issue of whether the unbundling of nature into marketable commodities is desirable and consistent with an overall national wetlands policy, but I'll save that discussion for another occasion.

\section{ENDNOTES}

1. Ralph E. H. Sims, et al. Energy Crops: Current Status and Future Prospects, 12 Global Change Biology 2054 (2006).

2. Lester R. Brown, Why Ethanol Production Will Drive World Food Prices Even Higher in 2008. Available at http://www.earthpolicy.org/Updates/2008/Update69.htm, January 24, 2008.

3. Timothy Searchinger, et al., Use of U.S. Croplands for Biofuels Increases Greenhouse Gases Through Emissions from Land-Use Change, 319 SCIENCE 5867, February 29, 2008, pp.1238-1240. Conversion of prairie potholes to corn cropland is also a concern. Jim Ringelman, et al, Biofuels: Impacts on Prairie Pothole Wetlands, 30 National Wetlands Newsletter 1 (2008).

4. Richard Hamilton, Biotechnology for Biofuels Production. Available at http://www.aspeninstitute.org/atf/cf/\%7BDEB6F227659B-4EC8-8F84-8DF23CA704F5\%7D/EEEethanol5.pdf.

5. Monique Hoogwijk, Potential of Biomass Energy Out to 2100, for Four IPCC SRES Land-Use Scenarios, 29 BIOMASS AND BIOENERGY 225 (2005).
6. D. R. Dubbe, Production of Cattail (Typha spp.) Biomass in Minnesota, USA, 17 BIomass 79 (1988).

7. Elisabeth Rosenthal, New Trend in Biofueis Has New Risks, New York Times, May 21, 2008

8. Allison Fox, A Giant Reed Conundrum, Wetland Weeds, Sept. 2007 at 4.

9. S. Raghu, et al., Adding Biofuels to the Invasive Species Fire? SGIENCE, Sept. 22, 2006, at 1742.

10. Assessing the Risk of Invasive Alien Species Promoted for Biofuels, The Global Invasive Species Programme. Available at http://www.gisp.org/whatsnew/docs/biofuels.pdf.

11. Carl Hershner and Kirk J Havens, Managing Invasive Aquatic Plants in a Changing System: Strategic Consideration of Ecosystem Service, 22 CONSERVATION BIOLOGY 544 (June 2008).

12. Martha Groom et al, Biofuels and Biodiversity: Principles for Creating Better Policies for Biofuel Production, 22 CONSERVATION BIoLogy 602 (June 2008).

13. Jacob N. Barney and Joseph M. DiTomaso, Nonnative Species and Bioenergy: Are We Cultivating the Next invader? 58 BIOSCIENCE 65 and 67 (2008).

14. Emily A. Heaton, Frank G. Dohleman, and Stephen P. Long, Meeting U.S. Biofuel Goals with Less Land: The Potential of Miscanthus, 14 Global Change Biology (2008)

15. Rudolf M. Smaling, Environmental Barriers to Widespread implementation of Biofuels, ENVIRONMENTAL \& ENERGY LAW \& POUCY JoufNAL at 287 (2009). Available at http://www.law.uh.edu/eelpj/ publications/2-2/04Smaling.pdf.

16. Mauricio Rojas, Assessing the Engine Performance of Palm Oll Biodiesel, BIODIESEL MAGAZINE, Aug. 2007.

17. A. Hooijer, M. Sivius, H. Wosten, and S. Page, PEAT-CO Assessment of $\mathrm{CO}_{2}$ Emissions from Drained Peatlands in SE Asia. Delft Hydraulics Report Q3943 (2006). See a/so Peatland Degradation Fuels Climate Change, Wetlands International Report 2006.

18. Thomas Lovejoy, The Threat from Trees: Global Warming Isn't Just a Problem of Cars and Smokestacks but of the Chain Saw, Too, Newsweek, July 14, 2008.

19. Finn Danielsen, et al., Biofuel Plantations on Forested Lands: Double Jeopardy for Biodiversity and Climate, Conservation BIoLOGY, 2007 Society for Conservation Biology, available at http:// www3. interscience. wiley.com/user/accessdenied?|D=1215365 33\&Act $=2138 \&$ Code $=4717 \&$ Page $=/ \mathrm{cgi}-\mathrm{bin} /$ ftlltext $121536533 /$ PDFSTART.

20. See hitp://globalseawater.com.

21. Marla Dickerson, The Old Man Who Farms with the Sea, Los Angeles TIMES, July 10,2008 at A-1.

22. Eli Kintisch, Sowing the Seeds for High-Energy Plants, 320 Science Magazine 478 (April 25, 2008)

23. Xan Rice, Wildlife and Livelihoods at Risk in Kenyan Wetlands Biofuel Project, The Guardiav, June 24, 2008.

24. Bryson Bates, et al., ed., Climate Change and Water, Intergovernmental Panel on Climate Change Technical Paper VI at 65 (2008).

25. Ralph E. H Sims, et al., Energy Crops: Current Status and Future Prospects, 12 Global Change Biology 2054, 2065 (2006). 26. Richard Hamilton, Biotechnology for Biofuels Production. Available at $\mathrm{http}: / / \mathrm{ww}$ w.aspeninstitute.org/att/cf/\%7BDEB6F227659B-4EC8-8F84-8DF23CA704F5\%7D/EEEethanol5.pdf.

27. Edward M. Rubin, Genomics of Cellulosic Biofuels, 454 NATURE 841 (2008).

28. Vishwanath Patil, et al, Towards Sustainable Production of Biofuels from Microalgae, 9 INT. J. MoL. Scl. 1188 (2008). 29. Id.

30. Mark E. Huntley and Donald G. Redalie, $\mathrm{CO}_{2}$ Mitigation and Renewable Oil from Photosynthetic Microbes: A New Appraisal,

12 Mitigation and Adaptation Strategies foh Global Change at 573-574 (2006)

31. Peer M. Schenk, et al., Second Generation Biofuels: HighEfficiency Microalgae for Biodiesel Production, 1 BIOENERG. RES. 30 (2008). 
32. Associated Press, From $\mathrm{CO}_{2}$ to Algae to Biofuel? Missouri Partners to Send Coal-plant Gases into Ponds (Sept. 10, 2008). 33. Scott Harper, ODU Experiment on Turning Sewage into Algae-Based Biodiesel is Flourishing. THE NOFFOLK VIRGINIAN-PULOT, January $19,2008$.

34. Page, Lewis, Shell in Hawailan Algae Biofuel Pilot, THE REGISTER. Available at http://www.theregister.co.uk/2007/12/12/ shell_algae_biofuel_green_scum_plan.

35. Chevron Partners with Solazyme on Developing Biofuel from Algae, San Francisco Business Times. Available at http://www. bizjournals.com/eastbay/stories/2008/01/21/daily22.html. 36. E Shailaja Nair, Algae-Biofuel of the Future or Pipedream? PLATTS INSIGHT 34 (October 2008).

37. The Carbon Trust, Word's Leading Publicly Funded R\&D Algae Project Launched to Make New Sustainable Biofuel a Commercial Reality. Available at http://www.carbontrust.co.uk News/presscentre/algae-biofuels-challenge.htm.

38. Algae Biofuels Offer Enormous Promise, Face Tough Production and Cost Challenges to Scale. Available at http://www.green carcongress.com/2008/10/algae-biofuels.html. See also Bradley J. Fikes, Sapphire Energy Says Algae Can Relieve Dependence on Foreign Oil, North COUNTY Times, Nov. 13, 2008.

39. Peer M. Schenk, et al., Second Generation Biofuels: HighEfficiency Microalgae for Biodiesel Production, 1 BICENEAG. RES. 30 (2008).

40. Hu Quiang, et al., Microalgal Triacylglycerols as Feedstocks for Blofuel Production: Perspectives and Advances, 54 THE PLANT JOLPNAL 621 (2008).

41. Rachel G. Lattimore, B/oomin' Government! Environmental Laws and Regulations That May Impact Algae Production, presentation to the AFOSR-NREL Microalgal Lipid to Blofuels Workshop, February 20, 2008

42. It should also be noted that other types of renewable energy projects may impact wetlands. For example, in Britain, the government is studying a project to dam the estuary of the Severn River in Wales, an area that has a range of almost 50 feet between high and low tide. The dam would store water that flows in with the high tide, and release it to produce hydroelectric power as the tide goes out. The project will produce intermittent flooding of some intertidal wetlands. See James A. Paterson et al., Mitigation, Adaptation and the Threat to Biodiversity, 22 Cons. Biol. 1352, 1353 (2008). In the U.S. Great Plains, fears have been raised about the impact of wind farms and associated power lines on wetland birds. See http://www.pljvorg/cms/windenergy and on the whooping crane's migration routes to its wintering grounds in the Texas wetlands. Patrick Reis, Wind Power Could Doom Treasured American Bird, Land LetTer, Oct. 2, 2008. Hydroelectric power dams have also destroyed many wetlands.

43. Past experience with the loss of wetlands to aquaculture projects should engender a degree of caution about the effects of biofuel projects. Although rice farmers have long grown crayfish or ducks as an ancillary use without serious harm, most moder aquaculture projects are intense monocultures that effectively destroy other wetland functions. See WILLAM J. MirsCH AND JAMES G. Gosselnk, Wetlands 311 (Wiley, 4th ed. 2007).

44. Resolution X.3. The Changwon Declaration on Human WellBeing and Wetlands, 10th Meeting of the Conference of the Partles to the Convention on Wetlands, Novernber 4, 2008.

45. Gabrielle Walker and Sia David King, The Hot Topig: What We Can Do About Global Wafming, Harcourt, 164 (2008).

46. Dennis Hirsch et al., Emissions Trading-Practical Aspects, in Michael B. Geraafd, ed., Global Climate Change and U.S. Law 627. 651-658 (American Bar Ass'n 2007).

47. Principles to Address the International Policy Context, United States Climate Action Partnership (2008). http://www. us-cap. org/pdf/International_Principles_Paper.pdf.

48. Regional Greenhouse Gas Initiative, History, http://www. rggi.org; Western Climate Initiative, Draft Design of the Regional Cap-and-Trade Program, July 23, 2008. Available at http://www. westernclimateinitiative.org/ewebeditpro/items/0104F18808.pdf.

49. Richard Black, Business Chiefs Urge Carbon Curbs, BBC News (2008). Available at http://news.bbc.co.uk/2/hi/science/ nature/7464517.stm

50. Charles Forelle, French Firm Cashes in Under U.N. Waming Program, The WALL Street JoufnaL ONLNe, July 23, 2008. Available at http://online.wsj.com/article/SB 121677247656875573.html.
51. Michael Wara, Measuring the Clean Development Mechanism's Performance and Potential, 55 UCLA LAw Rey, 1759 (2008), and Robert N. Stavins, A Meaningful U.S. Cap-andTrade System to Address Climate Change, 32 HaRv. ENvTL. L. Rev. 293 (2008).

52. Carbon 2008: Post-2012 is Now, Point Carbon News, March 27, 2008. Avallable at http://www.pointcarbon.com/research/ carbonmarketresearch/analyst/1.912721.

53. $1 d$.

54. David Greising, The Carbon Frontier, BuLEIN OF THE ATOMLC SCEENTISTS, JUly/Aug. 2008 at 32.

55. http://www.ieta.org.

56. Nigel T. Roulet, Peatlands, Carbon Storage, Greenhouse Gases, and the Kyoto Protocol: Prospects and Significance for Canada, 20 Wetlandos 605 (2000).

57. William J. Mitsch and James G. Gosseunk, Wetlandos, 318 (Wiley 4th ed. 2007).

58. Methane Emissions Increased from 2006 to 2007 at the Highest Annual Rate Since 1998. WMO Greenhouse Gas BuLtetr, Nov. 14, 2008; M. Rigby et al, Renewed Growth of Atmospheric Methane, 35 Geophrs. Res. LeTters L22805 (2008).

59. Intergovernmental Panel on Climate Change, Report of Working Group 1, p. 542, 2007. See also Wexin Ding, et al., Pre liminary Budget of Methane Emissions from Natura/ Wetlands in China, 38 Atmosphefic Environment 751 (2004); Hiram Levy 1 , et al., ed., Climate Projections Based on Emissions Scenarios for Long-Lived and Short-Lived Radiatively Active Gases and Aerosols, report by U.S. Climate Change Science Program at 65 (2008).

60. Intergovernmental Panel on Climate Change, Report of Working Group l, §7.4.2, (542-547) 2007.

61. Intergovernmental Panel on Climate Change, Report of Work ing Group I, p.543, 2007.

62. Sarah A. Bekessy and Brenda Wintle, Using Carbon Invest ment to Grow the Biodiversity Bank, 22 Cons. Biol. 510 (2008)

63. R. Kefry Tuaner et al., Valuing Ecosystem Services: The Case of MuLti-FunCtional WelLANDS, 96 (Earthscan, 2008).

64. Point Carbon, CARBon 2008, p. 31 (March 11, 2008).

65. Ferdinand E. Banks, The Poltical. Economy of Worid Energy. AN INTRODUCTORY TEXTBOOK (World Scientific, 280-281 (2007)).

66. Christina K. Harper, Climate Change and Tax Policy, 30 B.C INTL. \& COMF. L. Rev. 411 (2007).

67. Nigel Roulet, et al., Northern Fens: Methane Flux and Climactic Change, 44B Teluus at 100 (1992).

68. Lena Strom, et al., Greenhouse Gas Emissions from a Constructed Wetland in Southern Sweden, 15 WetLands Ecol. MGMT. 43 (2007).

69. Kewei Yu, Stephen P. Faulkner, and Michael J. Baldwin, Effect of Hydrological Conditions on Nitrous Oxide, Methane, and Carbon Dioxide Dynamics in a Bottomland Hardwood Forest and its implication for Soll Carbon Sequestration, 14 GLoBaL CHANGE Biology (2008).

70. Anne E. Altor and William J. Mitsch, Methane and Carbon Dioxide Dynamics in Wetland Mesocosms: Effects of Hydrology and Soils, 18 ECOLOGICAL ApPuications 1307 (2008).

71. Sudip Mitra, et al., An Appraisal of Global Wetland Area and its Organic Carbon Stock, 88 CURRENT SCIENCE 10 (2005).

72. J.R. Freney, Nitrous Oxide Emissions: Agricultural Soils, ENCYCLOPEDIA OF SOIL SGIENCE (2006).

73. Anne E. Altor and William J. Mitsch, Methane Flux From Created Riparian Marshes: Relationship to Intermittent Versus Continuous Inundation and Emergent Macrophytes, 28 Ecolog CAL ENGINEERING (2006).

74. T. Tokida, et al., In Situ Accumulation of Methane Bubbles in a Natural Wetland Soil, 56 EUAOPEAN JOURNAL OF SOL SCIENCE 389 (2005).

75. Ned Euliss Jr., et al., North American Prairie Wetlands are mportant Nonforested Land-Based Carbon Storage Sites, 361 SCIENCE OF THE TOTAL ENVIRONMENT 179 (2006).

76. Christopher J. Anderson, et al., Temporal and Spatial Development of Surface Soil Conditions at Two Created Riverine Marshes, 34 J. Envifon. Qual. 2072 (2005).
77. Torbjorn Johansson, et al., Decadal Vegetation Changes in a Northern Peatland, Greenhouse Gas Fluxes and Net Radiative Forcing, 12 Global Change Biology (2006).

78. K.M. Walter, et al., Methane Bubbling from Siberian Thaw Lakes as a Positive Feedback to Climate Warming, 443 NatuRE 71, September 2006. A recent study found that large bursts of methane are also released when freezing occurs in the fall. Mikhail Mastepanov, Large Tundra Methane Burst During Onset of Freezing, 456 NaTuRE 628 (2008)

79. P.M. Crill, et al, Methane Flux from Minnesota Peatlands, 2 GLOBAL BIOGEOCHEMICAL CYGLES 371 (1988).

80. Eric A. Davidson and Ivan A. Janssens, Temperature Sensitivity of Soil Carbon Decomposition and Feedbacks to Climate Change, 440 NaTuRE 165 (2006).

81. United Press International, Study: Tropical Wetlands Store More Carbon, available at www.upi.com/Science News/2008/ 10/09/Study_Tropical_wetlands_store_more_carborVIUPI19291223578899.

82. Diane E. Allen, et al., Spatial and Temporal Variation of Nitrous Oxide and Methane Fux Between Subtropical Mangrove Sediments and the Atmosphere, 39 SOL. BIOLCGY \& BIOCHEMISTRY (2007).

83. Artije Strangmann, et al., Methane in Pristine and Impaired Mangrove Solls and its Possible Effect on Establishment of Mangrove Seedlings, 44 BIOL. FERTLL SolLs 511 (2008).

84. H. Biswas, Spatial and Temporal Patterns of Methane Dynamics in the Tropical Mangrove Dominated Estuary, NE Coast of Bay of Bengal, India, 68 Jgurnal of MaAine Systems 55 (2007).

85. P.J. Crutzen, et al., $\mathrm{N}_{2} \mathrm{O}$ Release from Agro-Biofuel Production Negates Global Warming Reduction by Replacing Fossil Fuels, 8 Atmos. Chem. Phrs, 389 (2008).

86. Lihua Zhang, et al., The Variation of Methane Emission from Freshwater Marshes and Response to the Exogenous $N$ in Sanjiang Plain Northeast China, 41 ATMOSPHERIC ENMironMEN 4063 (2007)

87. ld.

88. Jianbo Cui, et al., Linkage of MIKE SHE to Wetland-DNDC for Carbon Budgeting and Anaerobic Biogeochemistry Simulation, 72 BIOGEOCHEMISTRY 147 (2005).

89. Kewel Yu, Stephen P. Faulkner, and Michael J. Baldwin Effect of Hydrological Conditions on Nitrous Oxide, Methane, and Carbon Dioxide Dynamics in a Bottomland Hardwood Forest and its implication for Soil Carbon Sequestration, 14 GLogAL CHANGE BioLOGY (2008).

90. M. Strack, et al., Sedge Succession and Peatland Methane Dynamics: A Potential Feedback to Climate Change, Ecosystevs (2006).

91. Virginia Bouchard and Matthew Cochran, Wetlands and Carbon Sequestration. 1 ENGYCLOPEDIA OF SOL SCENCE 1887 (2006).

92. Anna Laine, et al., Methane Flux Dynamics in an Irish Lowland Blanket Bog, 299 PLANT Soll 181 (2007).

93. Jamie Smialek, et al., Effect of a Woody (Salix Nigra) and an Herbaceous (Juncus Effusus) Macrophyte Species on Methane Dynamics and Denitrification, 26 Wetlands June 2006.

94. Yanhua Wang, et al., Nitrous Oxide Emissions from Polyculture Constructed Wetlands: Effect of Plant Species, 152 ENvironMENTAL POLUUTION (2008).

95. K. Krithika, R. Purvaja, and R. Ramesh, Fluxes of Methane and Nitrous Oxide from an indian Mangrove, CURRENT SCENCE, Jan. 25,2008 at 218

96. Peer M. Schenk, et al., Second Generation Biofuels: HighEfficiency Microaigae for Biodiesel Production, 1 BIOENERG. Res. 30 (2008).

97. Stephen W. Running, Ecosystem Disturbance, Carbon, and Climate, 321 SCIENCE 652 (2008).

98. Assessment on Peatlands, Biodiversity, and Climate Change, UNEP at 7-14 (2007). Similar problems can also occur in subarctic regions. Nakano, Tomoko, et al, Temporal Variations in Soil-Atmosphere Methane Exchange After Fire in a Peat Swamp Forest in West Siberia, 52 Sol- SGIENCE ANd PLANT Nutrition 77 (2006). Wetland fires can also increase other forms of air pollution. UNEP, Atmospheric Brown Clouds: Regional Assessment Report with Focus on Asia (2008) 
99. Willam J. Mitsghand James G. Gosselnk, Wetlands 181 (Wiley 4th ed. 2007).

100. Oswald Van Cleemput and Pascal Boeckx, Nitrogen and its Transfomations, 1 ENCYCLOPEDIA O= SOL SCIENCE 1125 (2006). 101. Lena Strom, et al., Greenhouse Gas Emissions from a Constructed Wetland in Southern Sweden, 15 WeTLANDS ECOL. MaMT. 43 (2007).

102. P.J. Crutzen, et al., $\mathrm{N}_{2} \mathrm{O}$ Release from Agro-Biofuel Production Negates Global Warming Reduction by Replacing Fossil Fuels, 8 Atmos. CheM. PhYs. 389 (2008).

103. Jos T.A. Verhoeven, et al., Regional and Global Concerns Over Wetlands and Water Quality, 21 TRENDS IN ECOLOGY AND EvoluTion 96 (2006).

104. Antje Strangmann, et al., Methane in Pristine and Impaired Mangrove Soils and its Possible Effect on Establishment of Mangrove Seedings, 44 BIOL. FERTL SOLLS 511 (2008).

105. I. K. Kravchenko and A.A. Sirin, Activity and Metabolic Regulation of Methane Production in Deep Peat Profiles of Boreal Bogs, 76 MicRoaloLogy 6 (2007).

106. W. Andriesse and M.E.F. van Mensvoort, Acid Sulfate Soils: Distribution and Extent, ENCYCLOPEDIA OF SOL SCIENCES (2006). 107. Willam J. Misschi and James G. Gosseunk, Wenlands 193 (Wiley 4th ed. 2007).

108. Antje Strangmann, et al., Methane in Pristine and /mpaired Mangrove Solls and its Possible Effect on Establishment of Mangrove Seedlings, 44 BICL. FERTL Solss 511 (2008).

109. Diane E Allen, et al., Spatial and Temporal Variation of Nitrous Oxide and Methane Fux Between Subtropical Mangrove Sediments and the Atmosphere, 39 SOL BIoL. \& BICCHEM. (2007).

110. Vincent Gauci, et al., Sulfate Deposition and Temperature Controls on Methane Emission and Sulfur Forms in Peat, 71 BIOCHEM. (2004).

111. S.C. Whalen, Biogeochemistry of Methane Exchange between Natural Wetlands and the Atmosphere, 22 ENvirON. ENG. Sc. 73 (2005)

112. I.K. Kravchenko and A. A. Sirin, Activity and Metabolic Regulation of Methane Production in Deep Peat Profiles of Boreal Bogs, 76 MICROGIOLOGY 6 (2007)

113. Mark D. Bertness and Brian R. Silliman, Consumer Control of Salt Marshes Driven by Human Disturbance, 22 CONSERVATION Biology 618, June 2008.

114. Robert J. Naiman, et al., Beaver Population Fuctuations and Tropospheric Methane Emissions in Boreal Wetlands, 12 BOGEOCHEMISTAY 11 (1991).

115. Willam J. Mitsch and James G. Gosselink, Wetlands 438 (Wiley 4 th ed. 2007).

116. Sofie Sjogersten, et al., Habitat Type Determines Herbivory Controls Over $\mathrm{CO}_{2}$ Fluxes in a Warmer Arctic, 89 ECOLOGY 2104 (2008)

117. Paul L.E. Bodelier, et al., Animal-Plant-Microbe Interactions: Direct and Indirect Effects of Swan Foraging Behaviour Modulate Methane Cycling in Temperate Shallow Wettands, 149 OECOLOGIA 233 (2006).

118. Tomoko Nakano, et al.. Temporal Variations in Soil-Atmosphere Methane Exchange After Fire in a Peat Swamp Forest in West Siberia, 52 Soll Science and PLANT Nutrimion 77 (2006).

119. P. Bousquet, et al., Contribution of Anthropogenic and Natural Sources to Atmospheric Methane Variablity, 443 NaTure 439 (2006).

120. Amanda M. Nahlik and William J. Mitsch, The Effect of River Pulsing on Sedimentation and Nutrients in Created Riparian Wetlands, 37 J. Environ. Qual. 1634 (2008).

121. Williarn J. Mitsch, Creating Riverine Wetlands: Ecological Succession, Nutrient Retention, and Pulsing Effects, EcoLOGICA ENGINEEAING 25 (2005).

122. Compensating for Wetland Losses Under the Clean Water Act, National Research Council Report 135 (2001).

123. For a careful analysis of the complexities involved in corn modifying wetland values, see James Salzman and J.B. Ruhi, Currencies and Commodification of Environmental LaW, 33 STAN. L REV 607 (2000)

124. A project in the Sacramento-San Joaquin River Delta will plant tules and cattails on 400 acres of peat soils to replenish them. Jim Nickels, et al., USGS, Callfornia and UC Davis Begin Large-Scale Delta "Carbon Farm," USGS. Avaliable at http:// www.usgs.gov (2008).

125. Ronnie J. Haynes and Kathy O'Reilly-Doyle, Terrestria Carbon Sequestration in the Southeest, NaTional WetLANDS NeWSLTTEg 7 (Nov.-Dec 2008).

126. U.S. EPA, Water Qually Trading Toolkit for Permit Workers (August 2007); Conservation Technology Information Center, Getting Paid for Stewardship: An Agricultural Community Water Quality Trading Guide (July, 2006).

127. Paul Faeth, Fertule Ground: Nutrient Trading's Potential to Cost-EFfectively Improve Water Qualtry (World Resources Inst. 2000).

128. S.L. McGinnis, Watershed-based pollution trading develop ment and current trading programs, 2 ENvT'L ENG \& POLICY 161 (2001).

129. Nancy N. Rabalais, Hypoxia in the Gulf of Mexico, 12 Tul. ENVTL. L.J. 321, 321-22 (1999)

130. http://www.unep.org/Geo2000/english/0036.htm.

131. See e.g., Fu-Liu Xu, et al., The restoration of riparian wetlands and macrophytes in Lake Chao, 405 HydrCBIOLOGIA 169 (1999).

132. Robert H. Kadlec and Scott D. Wallace, Theatment Wetlands 13-20 (CRC Press 2nd ed 2009).

133. Willam J. Mitsch and James G. Gosselink, Wetlands 425 (Wiley 4th ed. 2007).

134. http://www.epa.gov/owow/watershed/trading/tradingmap. html.

135. Matthew T. Heberling et al, Incorporating Wettands in Water Quality Trading: Economic Considerations, NATIONAL WELLANDS NewsLetteA, Jan.-Feb. 2007, p. 6.

136. See Thomas K. Ruppert, Water Quality Trading and Agricuttural Nonpoint Source Pollution: An Analysis of the Effectiveness and Fairness of EPA's Policy on Water Quality Trading, $15 \mathrm{~V} L$. ENML. L.J. 1 (2004)

137. Rachel Kalman, Note: EPA's Mercury Cap and Trade Rule: An Environmental Injustice for Women, 13 CARDOzO J.L. \& GeNDER 111 (2006).

138. Separate statutes regulate air, water, and food. Susan $E$ Cowell, Law at the AirMater interface, 8 WIs. EnvL. L.J. 51 (2002); Robin Kundis Craig, Climate Change, Regulatory Fragmentation, and Water Triage, 79 U. CoLo. L. Rev. 825, 857-861 (2008).

139. New Jersey v. EPA, 517 F.3d 574 (2007).

140. K. Ramesh Redoy and Ronald D. Delaune, Biogeochemistay of WETLANDS 482-485 (CRC Press, 2008)

141. D.F. Grigal, Inputs and outputs of mercury from terrestrial watersheds, 10 Environmental Revew 1, 29 (2002).

142. J.M. Benoit, et al., Geochemical and Biological Controls over Methyimercury Production and Degradation in Aquatic Ecosys tems, in Y. CAI \& O.C. BRADS, EDS., BIOGEOCHEMSIAY OF ENURONMENTALIY IMPORTANI TRACE Elements 262 (Amer. Chem, Soc'y. 2003).

143. Carl P.J. Mitchell, et al., The Role of Wetlands in Methylmercury Production, National Wetlands Newsletter 1 (Sept.-Oct. 2008).

144. Jerty Jenkins, et al, ACID RAIN IN THE ADIRONDACKS: AN ENvIRONMENTAL HISTORY 171-72 (Cornell Univ. Press, 2007).

145. Susan Eapen and S.F. D'Souza, Prospects of genetic engineering of plants for phytoremediation of toxic metals, 23 BioteChnology Advances 97 (2005); Ute Krämer, Phytoremediation: novel approaches to cleaning up polluted soils, 16 CURAENT OPINON IN BIOTECHNOL OGY 133 (2005).

146. Sharon Lafferty Doty, Enhancing phytoremediation through the use of transgenics and endophytes, 179 New PHYTOLOGIST 318,325 (2008).

147. Satu Lyyra, Coupling two mercury resistance genes in Eastern cottonwood enhances the processing of organomercury, 5 PLANT BIDTECH. J. 254 (2007)

148. Robert L. Fischman, The National Wildlife Refuge System and the Hallmarks of Modern Organic Legislation, 29 ECOLCGY L.Q. 457, 2002; Matt Young, Rescuing the Duck Factory, available at http:// www.ducks.org/DU_Magazine/DUMagazineNovDec2008/4105/ RescuingtheDuckFactory.html.
149. See e.g., Nancy Shepherdson, Wetland Birds Demand Change, CHicago WLDERNess 15 (Summer 2008).

150. Andren P. Dobson, Conseavation and Biodnersity 33-57 (Scientific American Library Paperback, 1998).

151. Raymond D. Semlitsch, Moving Wetland Banking Towards Conservation Banking, National_ Wetlands NewSLetIEH 15 (Sept.Oct. 2008)

152. hitp://www. birds.cornell.edu/AllAboutBirds/BirdGuide/ Red_Knot_dtl.htm

153. http://www.dig.ca.gov/habcon/conplan/mitbank

154. http://www.dfg.ca.gov/habcon/conplan/mitbank/catalogue/ catalogue.html.

155. Raymond D. Semlitsch, Moving Wetland Banking Towards Conservation Banking, National Werlands Newsletrea 15 (Sept.Oct. 2008).

156. http://www.fws.gov/endangered/factsheets/banking_7_05.pdf. 157. A recent book provides an overview of conservation banks. Nathanie: Cafroll et Al., eds., Conservation and Blodversity Banking: A Guide to Setting Up and Running Biodivergity Chemit Thading Systems 69 (Earthscan Publications, 2007).

158. Jessica Fox and Anamaria Nino-Murcia, Status of Species Conservation Banking in the United States, 19 Cons. Blo. 996 (2005).

159. Royal C. Gardner, Legal Considerations, in NATHANIEL CARroll, et AL., EDS., Conservation and BIOdVEefsity Banking: A GuIde to Setting Up and Running Biodiveasity Gredit Trading Systems 69 (Earthscan Publications, 2007).

160. http://www.fws.gov/endangered/factsheets/banking_7_ 05.pdí.

161. Royal C. Gardner, Legal Considerations, in Nathaniel CaAhOL et AL, EDS., Conservation AND BIDDIVEASITY BANKING: A GUIDE to Setting Up and Running Blodvenstry Credit Trading Systems 69, 73-76 (Earthscan Publications, 2007).

162. International Finance Corporation, Biodiversity Offsets and Opportunities, available at http://www.ifc.org/ffext/sustainability nst/AttachmentsByTitle/BiodivGuide_Offsets/\$FILE/Offsets.pdf.

163. Kerry Ten Kate and Mira Inbar, Biodiversity Offsets, in Nathaniel Cafpol, et al., eds., Consefvation and Biodiverstr BankIng: A Guide to Setting Up and Running Blooiversity Credt Trading SYsTems 189 (Earthscan Publications, 2007)

164. http://www.foresttrends.org/biodiversityoffsetprogram 165. Sarah A. Bekessy and Brendan A. Wintle, Using Carbon investment to Grow the Biodiversity Bank, 22 Cons. Biol. 510 $51.2(2008)$

166. See U.S. EPA, Mifigation Banking Factsheet, available at hitp://www.epa.gov/owow/wetlands/facts/fact16.html.

167. Rebecca L. Kihslinger, Success of Wetland Mitigation Projects, National Weilands NewsLetter, March/April 2008 at 14; Robert P. Brooks, et al., Are We Purveyors of Wetland Homogeneity? A Model of Degradation and Restoration to improve Wetland Mitigation Performance, 24 ECOLOGICAL ENGINEEEING 331 (2005). 168. Compensating for Wetland Losses Under the Clean Water Act, National Research Council Report (2001).

169. 13 U.S.C. $\$ 1344$

170. Rebecca L. Kihslinger, Success of Wettand Mitigation Projects. Natonal Wetlands Newstrter 14, March-April 2008.

171. Compensating for Wetland Losses Under the Clean Water Act, National Research Council Report 152 (2001).

172. Compensating for Wetland Losses Under the Clean Water Act, National Research Council Report 160-164 (2001).

173. Compensatory Mitigation for Losses of Aquatic Resources 73 Fed. REG. 19594 (2008).

174. Environmental Law Institute, The National Forum on Syner gies Between Water Quality Trading and Wetland Mitigation Banking 4-5, January 2006. Available at http://www.elistore. org/reports_detail.asp?!D=11125.

175. 73 FED. REG. 19673-19676.

176. David T. Urban, Rule Offers Philosophy Change to Mitigation. National Wetlands Newsletter 5, July-August 2008.

177. U.S. EPA, Mitigation Banking Factsheet. Available at http:// www.epa.gov/owow/wetlands/facts/fact16.html. Mitigation Bank managers have formed a trade association and are working on a clearinghouse for mitigation bank information. See http://www mitigationbanking.com. 